\title{
Universiteit
}

Leiden

The Netherlands

\section{Mixtec Cultural Vocabulary and Pictorial Writing}

Jansen, M.E.R.G.N.; Perez, G.A.; Carlin E, van de Kerke S

\section{Citation}

Jansen, M. E. R. G. N., \& Perez, G. A. (2010). Mixtec Cultural Vocabulary and Pictorial Writing. Linguistics And Archaeology In The Americas: The Historization Of Language And Society, 45-82. Retrieved from https://hdl.handle.net/1887/15689

Version: $\quad$ Not Applicable (or Unknown)

License: $\quad$ Leiden University Non-exclusive license

Downloaded from: https://hdl.handle.net/1887/15689

Note: To cite this publication please use the final published version (if applicable). 


\section{Linguistics and Archaeology in the Americas}

The Historization of Language and Society

\section{Edited by}

Eithne B. Carlin and Simon van de Kerke

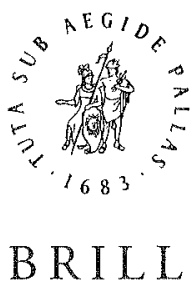


This book is printed on acid-free paper.

Library of Congress Cataloging-in-Publication Data

Linguistics and archaeology in the Americas : the historization of language and society / edited by Eithne B. Carlin and Simon van de Kerke.

p. cm. -- (Brill's studies in the Indigenous languages of the Americas; v. 2)

Includes bibliographical references and index.

"This book has been written by a select group of leading international scholars of Amerindian studies in honour of Professor Willem Adelaar on the occasion of his 60 th birthday in 2008."

ISBN 978-90-04-17362-0 (alk. paper)

1. Indians of South America--Languages-Grammar, 2. Indians of North America-Languages-Grammar. 3. Indians of South America-Languages. 4. Indians of North America--Languages. 5. Language and culture. 6. Archacology. 7. Adelaar, Willem F. H. I. Carlin, Eithne. II. Kerke, Simon van de. III. Title. IV. Series.

\section{PM5008.L562010}

$$
498-\mathrm{dc} 22
$$

2010005005

Copyright 2010 by Koninklijke Brill NV, Leiden, The Netherlands. Koninklijke Brill NV incorporates the imprints BRILL, Hotei Publishing, IDC Publishers, Martinus Niboff Publishers and VSP.

All rights reserved. No part of this publication may be reproduced, translated, stored in a retrieval system, or transmitted in any form or by any means, electronic, mechanical, photocopying, recording or otherwise, without prior written permission from the publisher.

Authorization to photocopy items for internal or personal use is granted by Koninklijke Brill NV provided that the appropriate fees are paid directly to The Copyright Clearance Center, 222 Rosewood Drive, Suite 910 Danvers, MA 01923, USA

Fees are subject to change.

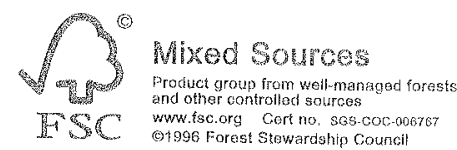




\title{
MIXTEC CULTURAL VOCABULARY AND PICTORIAL WRITING
}

\author{
Maarten E.R.G.N. Jansen \& Gabina Aurora Pérez Jiménez
}

\section{Introduction}

The language of a people is the key to its culture, including its worldview, technology, art, memory and social organisation.' The diachronic development of a language, and its expression in different stages of writing and literature, tells us much about the historical experiences and successive synchronic relationships of the community that uses it, from early archaeological times until today. It is not a pure immutable "essence" that we are looking for, on the contrary: it is the dynamics of development, the complex interplays of continuities, changes, creativities and internal contradictions, which are the most interesting, as they bring us in contact with the human condition of a community and its journey through time and space, its "nomadic identity" (cf. Braidotti 1994). A guideline for this interest and research endeavour is the cultural vocabulary of the people in question, which can help us to connect the present to earlier phases. This is particularly relevant in the study of the Mesoamerican cultural and linguistic heritage, which often includes ancient and colonial forms of writing and communicative visual art, as well as oral traditions. This heritage is not just a curious collection of objects and artefacts from the past, to be enjoyed or fantasized about by outsiders, but is of direct value to living descendant communities.

1. This contribution is a result from on-going research on Nuu Dzaui (Mixtec) language and culture, being carried out at the Faculty of Archaeology and the Centre of Non-Western Studies, Leiden University, with the support of the Netherlands Foundation for Scientific Research (NWO). We gladly acknowledge here the many years of fruitful cooperation with Willem Adelaar, who has played a central role in constructing an area of expertise and research on Native American languages and cultures at Leiden University. 


\section{Mixtec civilization}

The Nuu Dzaui or Mixtec people in Southern Mexico are one of the Mesoamerican peoples that play a central role in cultural historical and linguistic research at Leiden University. Nuu Dzaui (also pronounced N̂u Savi, Ñuu Sau, Nuu Davi and Nuu Dau, according to dialect variation) means "People or Nation of the Rain", ñuu being a comprehensive term for a place (town, city, country) and the people that live there, and Dzaui (in colonial orthography: Dzavui or Dzahui) is the word for "rain", as well as the name of the Rain God (the Tlaloc of the Aztecs and Chac of the Maya). The term "Mixtec" is derived from the name the Aztecs gave to this people in their language, (Nahuatl): mix-tecâ, "inhabitants of the land of the clouds".

The Mixtec land, referred to as 'La Mixteca' in Spanish, is located in the south of Mexico, in the western part of the State of Oaxaca and neighbouring areas of the States of Puebla and Guerrero. Ecologically this region is subdivided in three zones: 1) the Mixteca Alta, a mountainous area, mostly over 2000 meters above sea level, with a relatively cold climate, 2) the Mixteca Baja, lower but still quite mountainous, hot, dry and eroded, and 3) the Mixteca de la Costa, humid and tropical lowlands bordering on the Pacific Ocean.

The Mixtec language, Dzaha Dzaui (Sahan Savi, Sahin Sau, Daha Davi etc.) or "Language of the Rain", is reported to be spoken at present by more than 450.000 people, most of whom, however, are over twenty-five years of age. It belongs to the Otomangue family and is a tone language.

A rich heritage of archaeological sites, monuments and visual art bears testimony to the autonomous development of Nuu Dzaui culture from the first millennium B.C. onward till the Spanish invasion (1521). Summarizing the complex and fragmentary archaeological data, we see between approximately $500 \mathrm{BC}$ and the Spanish conquest of $1521 \mathrm{AD}$ the rise of a village-state culture, with impressive ceremonial centres of stone architecture (pyramids, plazas, tombs, ball-courts etc.), dispersed over the mountainous countryside, hardly known, less protected, and consequently subject to erosion and/or destruction. ${ }^{2}$

The development of a graphic register accompanies this development. Leaving aside the even more ancient rock paintings, we find in-

2. Archaeological information about Oaxaca is synthesized in The Cloud People, edited by Flannery and Marcus (1983) and in the monograph by Spores (2007). 
scriptions of calendrical signs (fixing dates and /or the calendrical names of persons) in the Late Preclassic period (approximately 500 B.C. - A.D. 200). In the following Classic period (A.D. $200-900$ ) this epigraphic record becomes more extensive, including statements about enthronements, rituals and conquests in a combination of pictorial (iconic) and hieroglyphic signs, clearly influenced by the important Zapotec capital Monte Albán in the Valley of Oaxaca. ${ }^{3}$

The archaeological and artistic hallmark of Nuu Dzaui civilization belongs to the Postclassic (A.D. 900-1521) and consists of a sophisticated, pregnant figurative style, used in paintings, sculpture, metallurgy and other art forms, generally synthesized under the term "Mixteca-Puebla style", shared by many Mesoamerican peoples in that period. This same style and representational code allowed for the elaboration of pictography, or pictorial writing, an original, precise and consistent system of graphic register, which uses mainly figurative (iconic) images in combination with specific conventional signs, also figurative in appearance but more ideographic (indexical, symbolic) and/or phonetic in nature. This system was employed in a corpus of polychrome painted manuscripts made of folded strips of deerskin (codices) or large pieces of cotton cloth (lienzos). Only a handful of such manuscripts have survived colonial destruction; the majority is now being kept outside the Mixtec region in museums or libraries in Europe, the U.S. or Mexico City. These unique and precious testimonies of the precolonial intellectual world register historical events, religious concepts and ritual practices.

We should stress that ancient Mexican pictography was not a rudimentary stage of some development towards phonetic writing. It was developed and used during some 1500 years in the central and southern parts of Mexico. Probably the Classic metropolis of Teotihuacan played a major role in its elaboration and distribution. We can still admire many of this pictography's fundamental conventions and stylistic aspects in the flamboyant frescoes of this archaeological site. At the same time, a phonetic writing system was developed in the Maya region (in the eastern part of Mexico, in Guatemala and Belize). The Mayas wrote hieroglyphic signs in sets of two parallel columns, top down. These hieroglyphs are generally composed of smaller signs that

3. For an overview of the development of Mixtec writing in its social context, see Jansen and Van Broekhoven (eds.) (2008). 
represent syllables in the local Maya language. Pictography, in contrast, is largely independent of language and represents the information directly through figurative scenes. Although the peoples of Central and Southern Mexico were in contact with the Mayas and must have had some knowledge about that form of phonetic writing with hieroglyphic signs, they preferred to stick with their pictography. Apparently, they saw several advantages in using this system of pictorial communication, such as its intelligibility across language boundaries indeed, many distinct languages were/are spoken in this part of Mexico. Another important advantage becomes evident when one studies the character of the languages in question: many are tone languages. For a phonetic writing system to work for them, a rather wide array of signs for syllables with different tones would have had to have been developed. But that is not all: in the tone languages words, or rather syllables, may change tone under the influence of words/syllables with other tones in the sentence melody (sandhi). It is quite cumbersome to develop a phonetic writing system that will adequately represent these dynamics. Also the modern alphabet is badly suited to represent this tonal aspect of a language. Pictography proved to be an excellent and easy answer.

\section{The linguistic work of the Dominican missionaries}

Products of early colonial times, but still outstanding in their extent and quality, are two major works of the Dominican Order, which after the Spanish invasion took on the evangelisation of the region: the Dzaha Dzaui grammar of Friar Antonio de los Reyes and the vocabulary compiled by Friar Francisco de Alvarado. Both were published in 1593, at the instigation of the Dominican provincial, Friar Gabriel de San José. On the one hand the friars followed the sixteenth century tradition of Spanish vocabularies and grammars, initiated by the humanist Antonio de Nebrija (1441-1521) who published his main work in the same year that Columbus undertook his first voyage. On the other hand, they based themselves on their own learning in practice from the speakers of Dzaha Dzaui. In this way their works are fascinating intercultural products, fruits of the interaction (and implicit dialogue) between Dominican monks and Ñu Dzaui intellectuals during many decades in the early colonial period. The texts contain valuable references to the traditional, precolonial world and worldview, giving 
terms for many items and details of the material culture and ancient technology, such as ceramics and textiles, but also of the social organisation, kinship, and religion. At the same time these works reflect how the introduction of new elements and ideas from Spain led to the creation of new expressions and neologisms. All of this, needless to say, is of crucial importance to archaeological and historical studies.

The dialect variety of Dzaha Dzaui registered by these Dominicans was that of Yucu Ndaa (Teposcolula), the alcaldia mayor of the Mixteca Alta and site of an impressive Dominican convent: this variety occupies a "central" position within the total dialect variability, so that its terms are very useful for etymological studies and for understanding the relationships between the different varieties of Mixtec through time. Unfortunately and ironically, in Yucu Ndaa (Teposcolula) itself, Mixtec is no longer spoken.

The works of Reyes and Alvarado are now indispensable keys for translating and understanding the corpus of colonial documents written in Dzaha Dzaui using the alphabet introduced by the Spaniards. ${ }^{4}$ Alvarado's vocabulary is comparable to other famous products of monks in those days, such as the Nahuatl dictionary of Friar Alonso de Molina (1571) and the Zapotec dictionary of Friar Juan de Cordova (1578). Only the Spanish - Mixtec part was published. Recently in Leiden, however, with the help of students of modern Mixtec, we have transcribed Alvarado's work into a data-base and so were able, after due analysis, to generate a counterpart Mixtec-Spanish dictionary.

It turns out to be relatively easy to establish the correspondences between this sixteenth century Yucu Ndaa dialect and the present-day dialects of the Mixtec language, e.g. the Sahin Sau of Nuu Ndeya (Chalcatongo), with which we, the authors, are most familiar. The main differences are quite regular phonetic changes. Once these transformations have been performed, an impressive continuity of terms and meanings demonstrates a profound time-depth of Mixtec cultural vocabulary.

Recently we were present at the preparation of some new cooking vessels for practical use. It was interesting to watch how the vessels were bathed with water in which a lot of chalk had been dissolved and then "cooked" on the three stones (yiyi) above the open kitchen fire.

4. For a first index see Josserand, Jansen and Romero (1984). Examples of these documents have been published by Jansen (1994) and Terraciano (2001). 


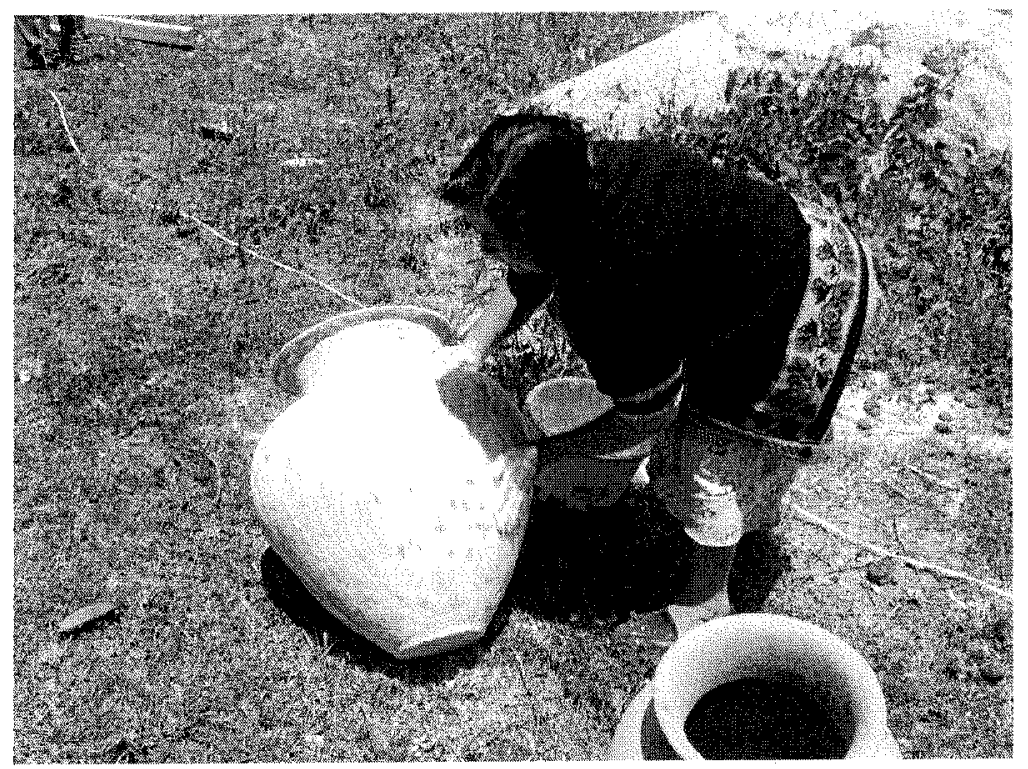

Fig. 1. Preparing (suhni) a vessel in Nuu Ndeya (a: bathing in chalk water)

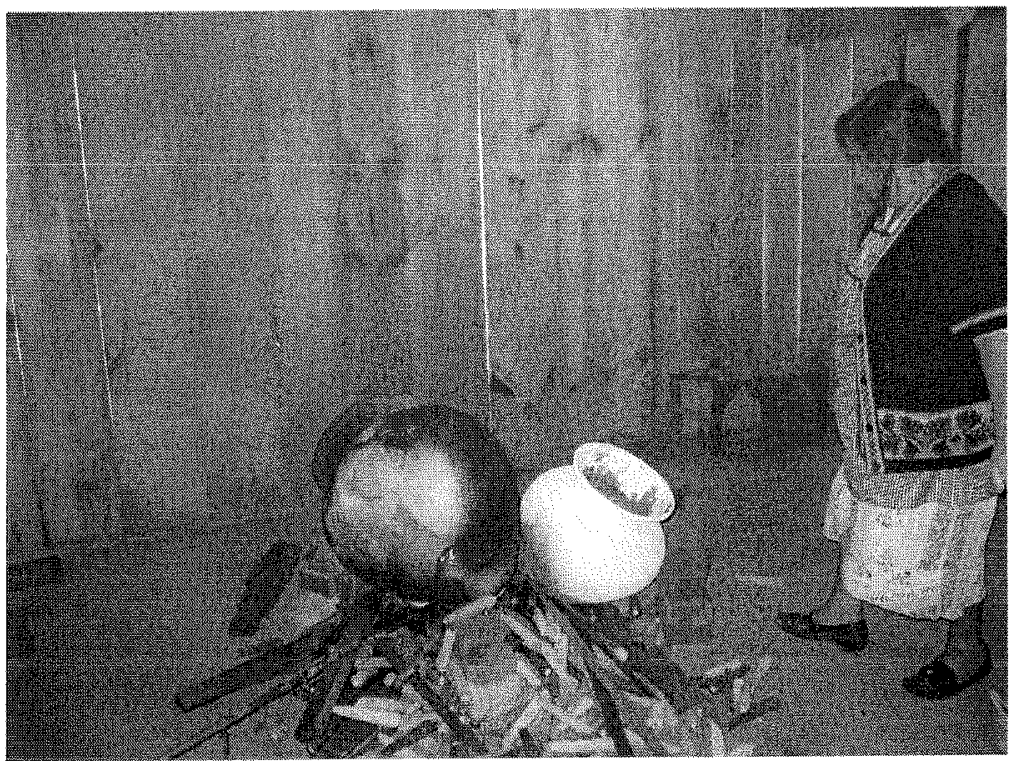

Fig. 2. Preparing (suhni) a vessel in Nuu Ndeya (b: cooking the vessel) 
People who know the tradition referred to this action with a specific verb: suhni, which, however, is not known any more among many other speakers of Sahin Sau. But it is the modern form of expressions registered in the sixteenth century dictionary by Friar Francisco de Alvarado: yodzuni, 'to use a new vessel' (Spanish: estrenar vasija), and even more specific in combination with the word for the cooking vessel: yodzunindi quedze, 'to heat the new vessels to make them strong' (Spanish: calentar las vasijas nuevas para que se fortifiquen).

In Alvarado's vocabulary the verb yodzuni(ndi) is also used for cooking water or milk, and is even reported to have a figurative meaning: yodzunindi huahi ñuhu, 'to dedicate the house of God' (Spanish: dedicar iglesia). This is an example of how a language stores much of its cultural memory in specific terminologies and ways of expression (cf. Assmann 1992). It goes without saying that it is crucial to document and study such cultural vocabulary and the related practices and concepts, in both a diachronic and an intercultural manner.

Interestingly, Alvarado registers several terms for 'paper that the Indians used for writing' (Spanish: papel en que escribian los indios antiguos), which correspond to the different materials for creating pictographic manuscripts: tutu 'paper', dzoo 'cloth', i.e. lienzo) and ñee 'skin', i.e. deerskin). In the words for 'rough, native paper' (Spanish: papel de estraza, o de la tiera), i.e. bark paper or amate, Alvarado documents several forms: tutu nuhu is indeed 'paper of the land', but tutu ñu dzuma 'paper of the Colhua' refers to Central Mexico, while tutu ñudzavui signals the existence of locally produced 'Mixtec paper'.

A book (codex) was ñu ñuhu 'sacred skin' and the man writing such a book (tay ninataa ñee $\tilde{n} u h u$ ) was a 'historian'. References to European style books (e.g. in libro impreso) use the term tutu 'paper', as is still the case today. Logically, given the pictorial character of precolonial Mixtec writing, an equivalent term for the ancient book was tacu'painting'.

The scenes of a codex correspond to the term of naa ndeye, translated as 'a memory image of the past' (Spanish: imagen otra para memoria de lo pasado, entre indios), and literally 'image of a dead person'. A 'line' (Spanish: renglón) within writing is yuq, a word also meaning 'furrow', connoting a linear sequence, and coinciding beautifully with the scientific term 'boustrophedon' for the "zigzag" reading order that is characteristic of the codices. 
Further interesting details: an inkpot is tiyaha tnoo 'a gourd of black stuff, and a pen is yeque taa tutu 'a bone for writing', although the Spanish translation, in accordance with its own cultural practice, refers to a feather: pluma.

The native terms for 'writing' (yotaa tutu) and 'reading' (yonacahui tutu), which appear in Alvarado's vocabulary must originally have referred to the writing/painting and reading of the precolonial codices. They are still in use today (chaa tutu and kahu tutu respectively), demonstrating that these arts and abilities were not introduced by the colonial invaders, but had already been developed much earlier. The verb yotaa 'to write' has a wider meaning as 'to mark' and was used by the monks also for 'crossing oneself' (Spanish: persignarse): yotaa tnuni, in which tnuni means 'signal' or 'sign'. Similarly, yocahui also means 'to count' and was used in the context of evangelisation for 'saying (praying) the rosary'. These semantic extensions are in accordance with the oral performance aspect of ancient pictorial writing.

As was to be expected, the painting of the figures often corresponds to figurative language. For example, in modern Nuu Ndeya (Chalcatongo) the expression for submission is chii shrehe 'to hold someone under the armpit'. Alvarado gives us yocuvui dzahi 'to be (under) the armpit' as expression for being subdued (Spanish: vencido ser). Indeed we find in Codex Añute (Selden), p. 12-I, a pictorial scene of battle and conquest in which a Mixtec ruler holds a Nahua warrior under his arm.

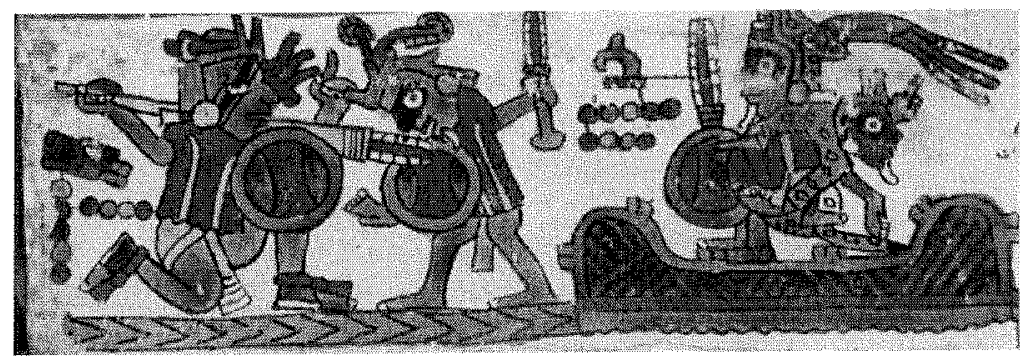

Fig. 3. Codex Añute (Selden), p. 12-I.

\section{Ceremonial speech}

As pictography does not have a direct, immediate relation with language, how is it read? Several early colonial manuscripts, such as the 
famous Codex Mendoza, contain glosses and comments in Nahuatl and/or Spanish that clarify the meaning of scenes and provide us with a basis to identify and read individual signs (cf. Nowotny 1959). Often it is possible to find the corresponding terms in Dzaha Dzaui, either directly or by comparing the entries in Molina's Nahuatl dictionary with the corresponding ones in Alvarado's work. But the written alphabetic texts in the codices were generally generated in the highly determined (if not stressful) context of a Spanish person enquiring about what the native pictures contained, rather than in the free context of original oral performance.

As for the historical codices of Nuu Dzaui, we observe that the contents are of a dynastic nature (creation of the royal lineage, deeds of mighty kings and queens, genealogy of the ruling family). In the Classic Maya area similar statements occur as inscriptions on steles and important buildings in the ceremonial centre. Apparently these texts were communicated to an audience as public reading, story-telling or dramatic performance during special ceremonial occasions. In fact, historiography itself may be considered part of a ritual act of commemoration: consequently it was imbued with religious thought and moral values.

We are well informed about the special language used on such occasions, not only in the case of the Maya and the Aztecs, but also in the case of Nuu Dzaui. Mesoamerican peoples in general used a ceremonial or reverential language, characterized first and foremost by parallelisms and metaphors, both in ritualised speeches or prayers and in sacred narratives (e.g. the Popol Vuh). Today in the Mixtec region this language is referred to by the Spanish term parangón and the Mixtec term sahu (shahun, sahvi, dahvi etc. depending on the dialect), which may be translated as 'formal or ceremonial discourse'. Recently Ubaldo López García (2007) has documented and analysed the present usage of this parangón in his native village, Yutsa Tohon (Apoala) in the Mixteca Alta, registering many examples of flowery discourse.

Paradoxically, it was the Dominican monks in the sixteenth century who studied and employed this language as part of their crusade against the native religion. The usage of such traditional literary performance conventions effectively demonstrated to the audience that the preacher knew how to speak well and lend solemnity to his words. Moreover, the parallelisms and metaphors of this ceremonial language were suitable for translating Biblical texts and Christian prayers, which 
often contain similar figures of speech. As an example we quote the prayer of St. Thomas, translated by friar Benito Hernández in his Doctrina en Lengua Mixteca, in the dialect of Yucu Ndaa (Tepozcolula), published in 1568:

Stoho ñuhu ndios,

Lord God (Ñuhu),

yya ndehe huaha, ndehe cuhui,

huadza nisiyo sahani,

huadza nicacuni,

Divine Lord, all good, almighty, you did not have a beginning,

huadza niqhuini, you were not born,

da hua qhndehe, hua qhnaani, you did not originate,

sadzehuini maani nisaandiyani

dehendu angeles

and you will not end nor perish;

you yourself created

da yni andehui nicoocuisiya,

all the angels,

now living in the heart of heaven,

nisaa sanuya,

they put down their chests (burdens),

niniy tahui tayuya,

received their seats

nisaqhendahuiya

and were counted

nanani, tayu maani.

before your countenance, your throne.

Da niquidzahuahani

And you made

dehe nuu, ndehendusi,

all forms, all types (of creatures)

sa caa, sa ysi

ñuuñayehui

dehendu sa sini ñuhu

lying down, standing upright

in the world,

dehendusi y[o]quidzatniñosi

all that is needed:

all perform their task

sa nicanadzanani,

sa nicuhuindiyani,

sa nidzasani

ndehe y[o]quidzasi

Sadzehuini maani

(yoo tuhui tucuca) nicuhuini,

dzahuatnaha nduta ñuhu

yocana neendu nina canu

yocay yosinonoo

as you have ordered them,

as you wanted,

as you distributed,

all are working.

And you yourself,

(no one else) you are

like the water of the sea

that engulfs the whole globe,

rises, runs,

ñuuñayehui siy andehui;

hua dzehuini

duta ñuนñayehui

yosito yosini ñadzaña.

on earth and in heaven;

But you are not just the same

as the water of the earth

that I see and observe. 


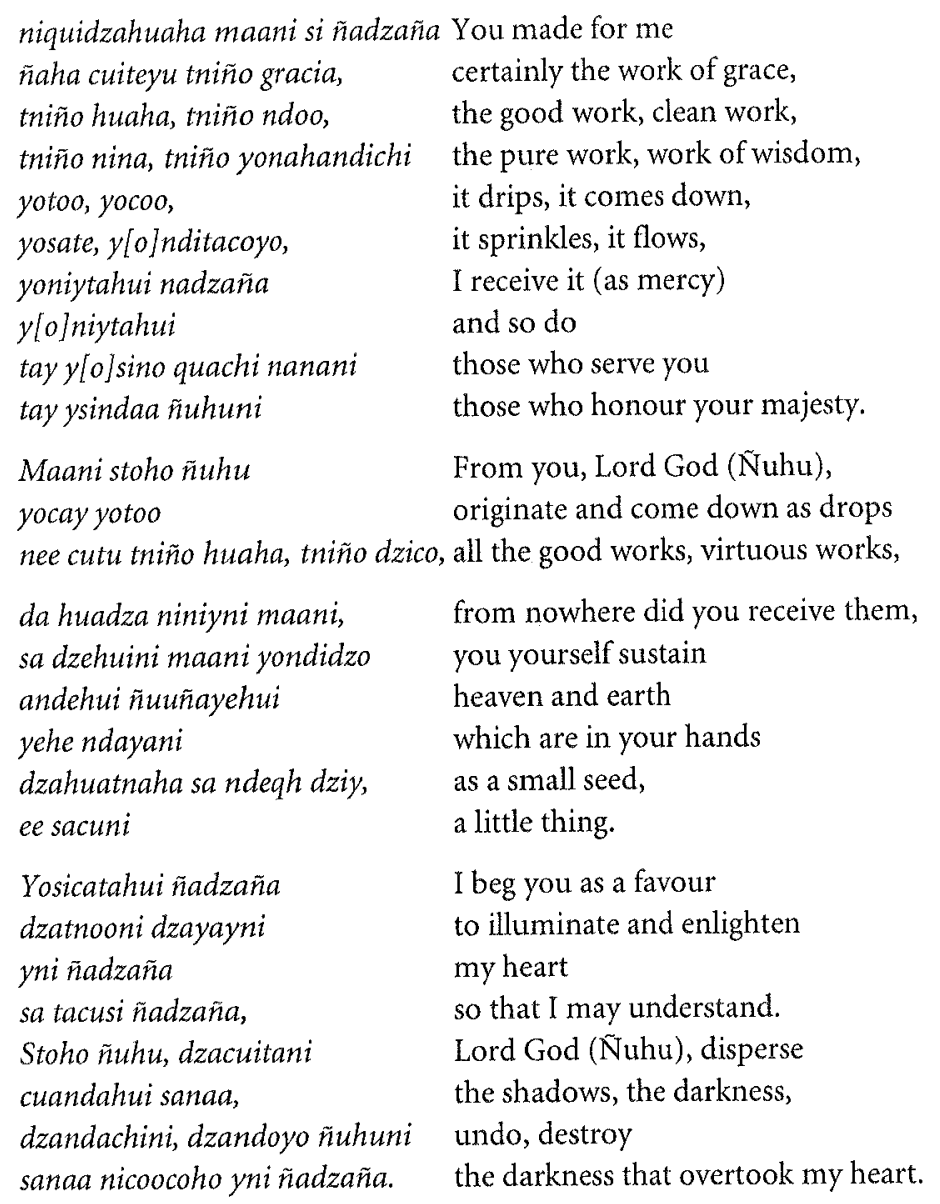

A special form of the parallelism is the difrasismo (hendiadys), which consists of a pair of nouns or verbs the combination of which creates a new meaning, such as quevui cuiya 'the year, the day', i.e. 'time', or yuvui tayu 'the mat, the throne', i.e. 'the kingdom' or 'the nation'. As the two words in such a construction are pronounced with a special emphasis and pause in between, there is no tone sandhi, as we may observe in modern Mixtec (Sahin Sau of Chalcatongo). Compare:

$k \dot{u} k^{w} i y a$ 'the day of the year' (tone sandhi in the second word)

$k \dot{u}, k^{w} i y a$ 'the day, the year', i.e. 'the time' (without tone sandhi). 
In the precolonial codices we find several examples of similar parallel constructions, represented by pairs of painted objects or figures. The largest number of these we find in the most ritual of all Mixtec manuscripts: Codex Yuta Tnoho (Vindobonensis), see Fig.4. ${ }^{5}$

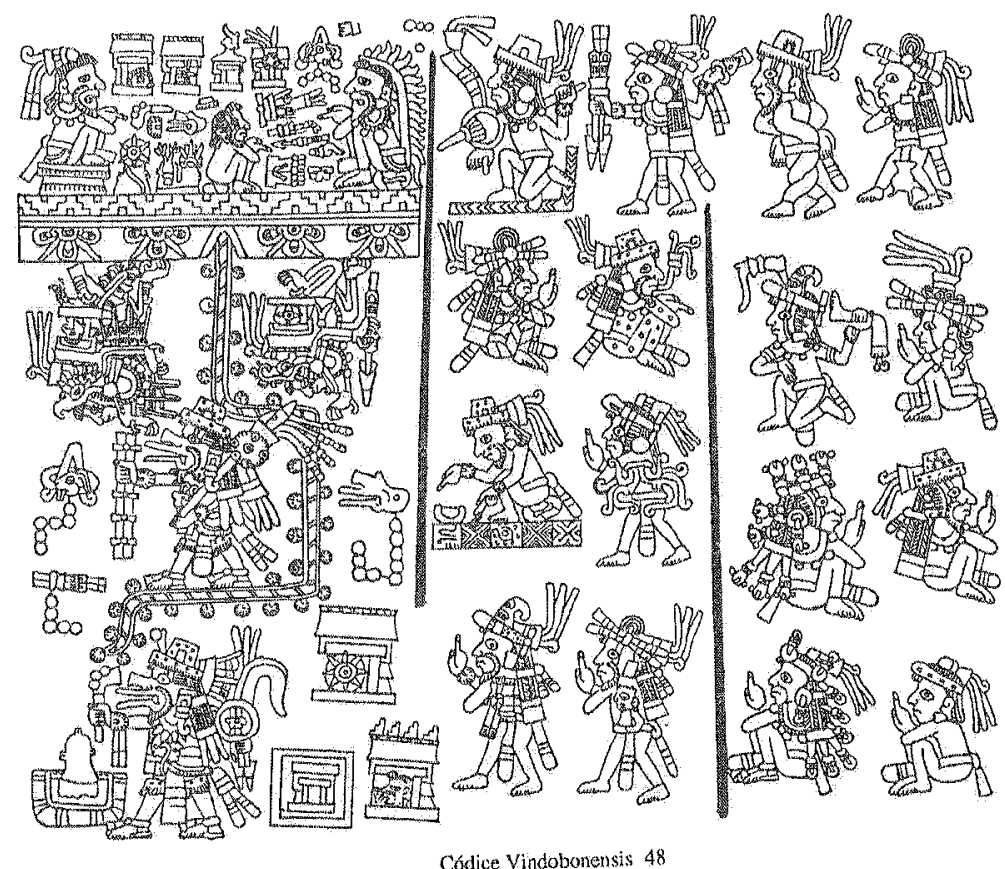

Fig. 4. Codex Yuta Tnoho (Vindobonensis), pg. 48 (reading order boustrophedon, from bottom right, to bottom left)

This principle operates, for example, in the list of titles of the main culture hero, the Whirlwind or Plumed Serpent, who is characterized as:

"Lord who carries jade, Lord who carries gold

(the difrasismo dzeque dziñuhu, "jewel, gold" is used to qualify the lord as the precious one, the one who gives richness and art).

5. Facsimile edition with commentary: Anders \& Jansen \& Pérez Jiménez 1992a. Here we employ the new nomenclature we proposed for the precolonial pictorial manuscripts (Jansen \& Pérez Jiménez 2004). 
Lord who throws darts (i.e. the conqueror),

Lord who carries shield and spear, and who is on the warpath (the difrasismo tatnu yusa, "spear, shield" is used to qualify the lord as a valiant warrior, the one who inspires courage)

Lord from whose heart the songs flow, Lord who is the painter of books, with the red and black paint (i.e. the one who inspires art and creativity).

Lord who carries in his heart the deity (Nuhu), Lord who carries in his heart the sacred bundle of sticks (symbolizing Authority and the Ancestors), ... (i.e. the pious one, the teacher of religious devotion)...

Lord (who transforms into) eagle, Lord (who transforms into) fire-serpent (The hendiadys iya yaha iya yahui, "Lord Eagle, Lord Fire-Serpent was translated in the $16^{\text {th }}$ century as 'nigromancer', i.e. shaman)

Lord who carries the Temple of the Flayed One Lord who carries the Temple of the Sun (i.e. the one in charge of the important month rituals known as Tlacaxipehualiztli and Panquetzaliztli in the Aztec language)"

The same principle appears in a large list of individuals on pages 30-27 of the same manuscript, see Fig.5. Their names are clearly ordered in pairs:

Lord 7 Rain 'Flayed God', 'War Eagle, War Jaguar'

Lord 12 Vulture 'Jaguar', 'Night Eagle, Night Jaguar'

Lord 7 Wind, 'Eagle that looks ahead and backward'

Lord 7 Movement 'Eagle of Flints', 'Owner of the Jaguar Temple',

Lord 9 Movement 'Eagle, holding Jade',

Lord 7 Deer, 'Jaguar holding Jade'...

Lord 7 Movement 'Jaguar', 'Jaguar on the Warpath'

Lord 10 Lizard 'Eagle', 'Jaguar in the Ball-court' 


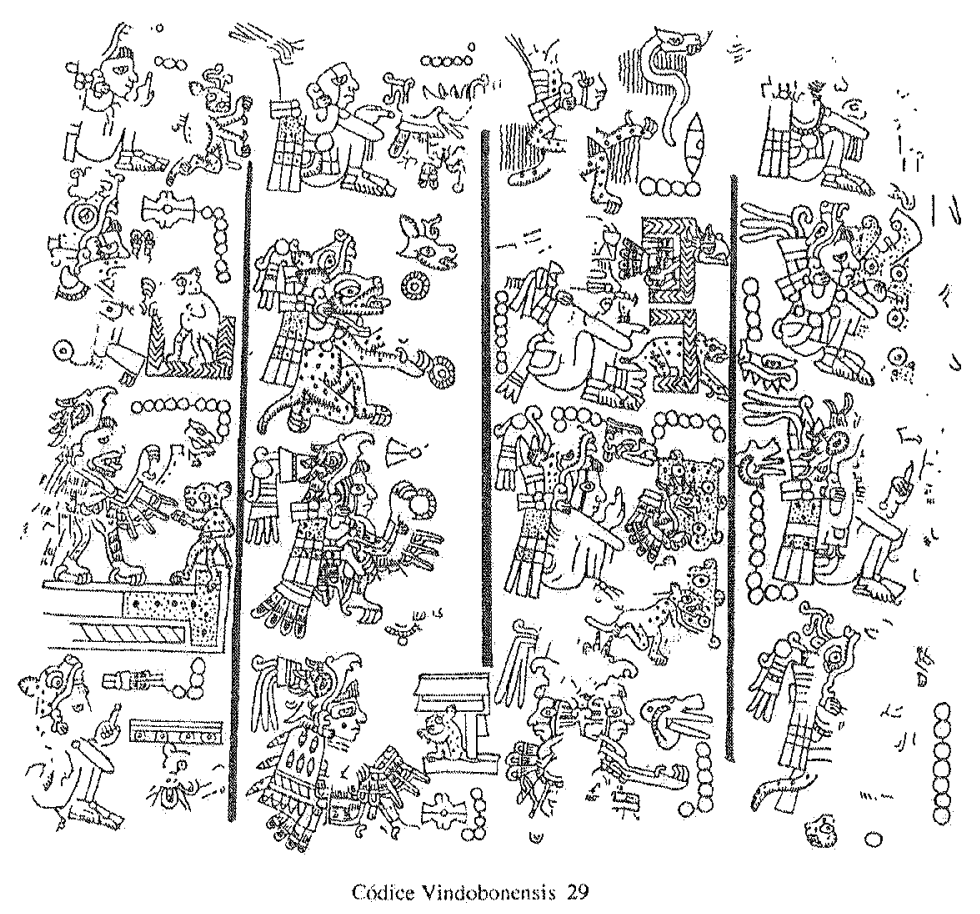

Fig. 5. Codex Yuta Tnoho (Vindobonensis), p. 29

Two women with the same calendar names and essentially the same given names appear next to each other (Codex Yuta Tnoho, p. 27-I), see Fig.6:

Lady 13 Flower 'Quetzal bird of jade'

Lady 13 Flower 'Quetzal bird of jade'

But the birds that appear as their name signs are painted in different manners and the ladies wear different hairdoes, both typical for women: the first has the braids with coloured bands (ndaha), the second the red lock of hair on the forehead (yoo tnaa). ${ }^{6}$ This suggests that

6. Alvarado registers for the braiding of the hair by women: yonaquina ndaha idzi dziniña (cabellos trenzar la mujer), for doing so with bands of cloth: yodzucundi ndaha and yonaqnindi ndaha (cinta tal poner con que se trenzan los cabellos), and specifies terms for the hairlocks on the forehead, yoo tnaa (copetillo de las muchachas en la frente) and tetnaa (cabellos copetillo de las muchachas en la frente). There seems to be 
the reading of the list could be performed by following a basic repetitive pattern of parallel terms, while at the same time adding specific elaborations.

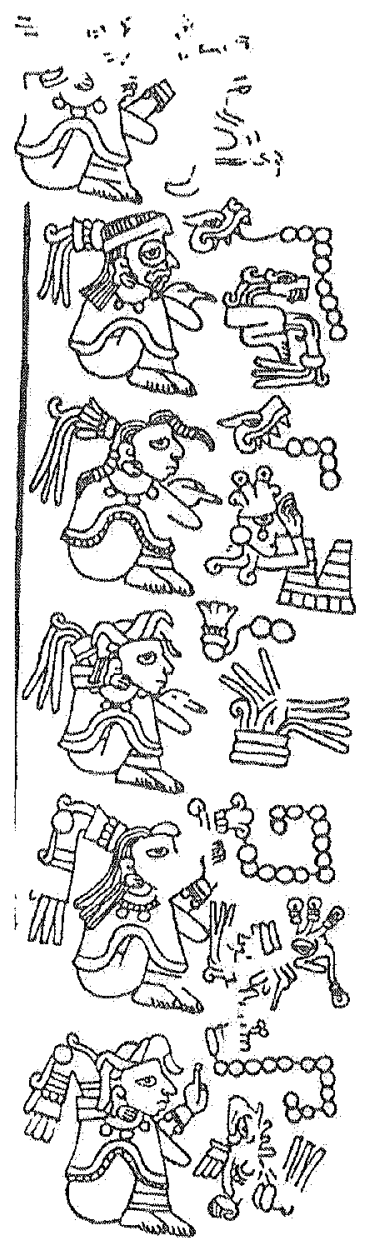

Fig. 6. Codex Yuta Tnoho (Vindobonensis), p. 27

no difference as to age or marital status of either form of hairdo in this codex: as we see these different forms associated with the same women. Compare Lady 1 Eagle on p. 24 and p. 23, Lady 9 Grass on p. 24 and p. 25. 
Among the ladies' given names we further find the parallel structure:

Lady 4 Dog 'Flower of War'

Lady 4 Wind 'Jade of Arrow'

Lady 6 Rain 'Flower of Jade, Flower of Gold, Band of Jade, Band of Gold'

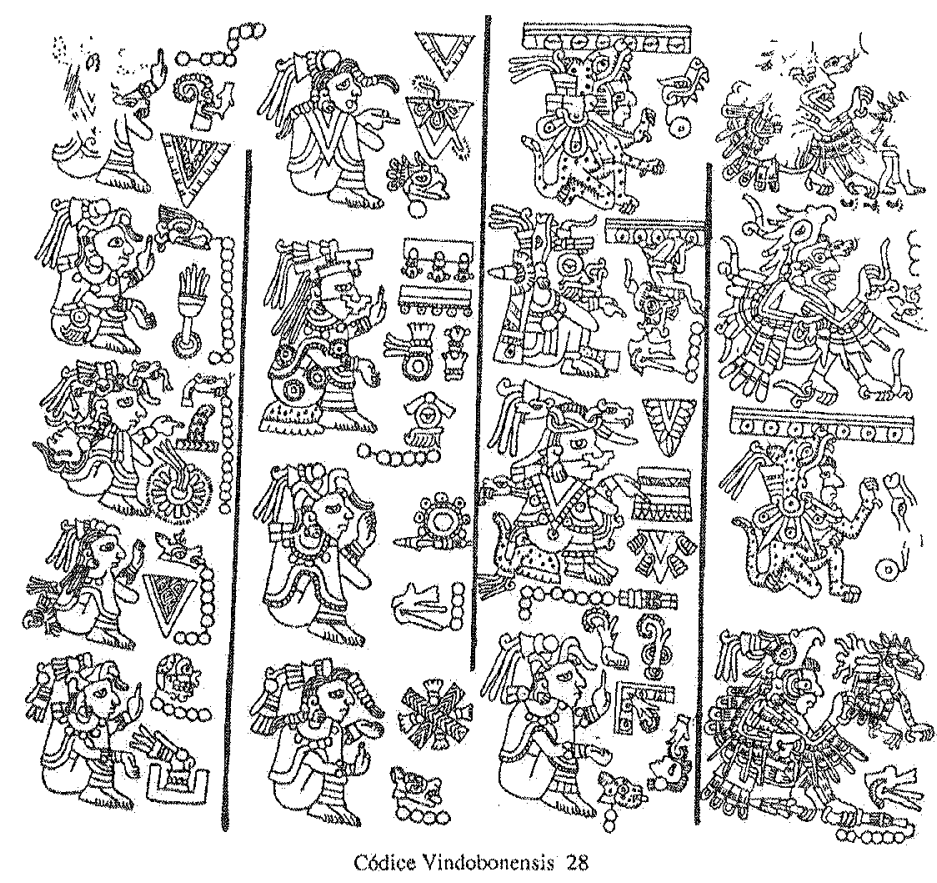

Fig. 7. Codex Yuta Tnoho (Vindobonensis), p. 28

On p. 28-II (see Fig. 7), a Lady 2 Jaguar appears with a fourfold name, consisting of four variants of the basic element 'maize flower', i.e. yoco, a word that can also mean 'breath' and occurs in the names of Gods.' Naha Yoco (combining yoco with ñaha 'female person') is a term for 'Virgin' and may express a generic title of this Lady. In her given name (or title) the maize flower occurs in combination with a hand, with three black beans, situated in a doubled sky and on the head of an up-

7. Yoco is paralleled with the Rain God on p. 24 of the same codex. Compare the Mixtec prayers from Guerrero, registered by Schultze Jena (1938) 
ward looking maiden. Most of these combinations do not produce a self-evident iconical reading, which leads us to suspect that a phonetic reading is intended. This hypothesis gives the most likely result if we suppose that the added signs do not refer to nouns but to verbal stems (which would have been preceded by the present-tense prefix $y o-$ ):

- Maize flower with hand ( $=$ ndaha): Yoco yondaha 'Spirit (or: Virgin) that gives satisfaction or healing'.

- Maize flower with beans (= nduchi: Yoco yonduchi 'Spirit (or: Virgin) that purifies'.

- Maize flower that was born in Heaven: Yoco nicacu ini Andevui 'Spirit that originates in the Heart of Heaven'.

- Maize flower with face (= nana): Yoco yonana 'Spirit (or: Virgin) that sprouts'. An alternative reading for face or eye would be nuu, which as a verb (yonuu) in combination with the preceding sign would suggest the act of coming down from Heaven.

Another personage in this list, Lady 9 Reed, is an important Goddess, who intervened crucially in the life of the famous warlord and ruler Lord 8 Deer 'Jaguar Claw' (cf. Jansen \& Pérez Jiménez 2007a). She has a name consisting of a poncho-like garment known in Mexico as a quechquemith, and a skirt, both decorated with flints. This quechquemitl we find in Mixtec as dzico, a word that can also mean 'virtue, power' while likely in the skirt it is the decorated rim or fringe that is intended, which in turn reads huatu, a word that can also mean 'pleasure' or 'glory'. The terms dzico and huatu form a difrasismo for 'good name' and 'glory of the Saints'. Here they appear as complementary parts of a given name 'Power of Knives, Glory of Knives'.

Added to this is yet another name: quechquemitl with shells, which likely is to be read as Dzico Yee 'Virtue and Strength', since yee means, on the one hand, 'shell' and on the other, 'valiant, constant, strong'.

There are several ladies in Nuu Dzaui history with quechquemitl names, probably to be read in this same way, as dzico 'power, virtue'. The given name of Lady 9 Wind, see Fig.8, queen of Añute (Jaltepec), was also Dzico Yuchi (Quechquemitl of Flints, i.e. 'Power of Knives'), probably in honour of the Goddess 9 Reed.

8. An Aztec parallel is the Goddess Itzpapalotl Itzcueye, "Obsidian Butterfly, She of the Skirt of Obsidian", who, according to the 'Treatise of Ruiz de Alarcón (1953), represents the power of the arrowhead. 


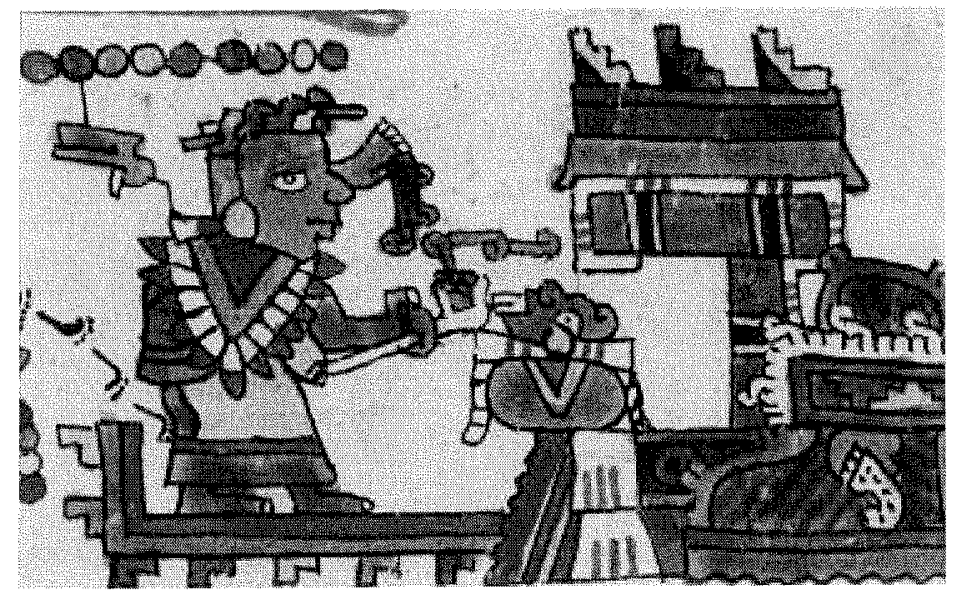

Fig. 8. Codex Añute (Selden), p. 5-III: Lady 9 Wind.

Her daughter, the famous princess 6 Monkey, see Fig.9, was called Dzico Coo Yodzo 'Power of the Plumed Serpent'.

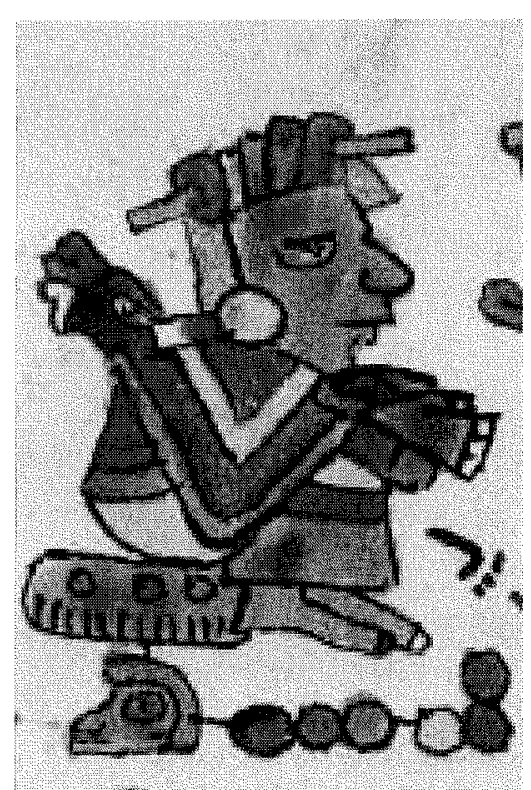

Fig. 9. Codex Añute (Selden), p. 6-III: Lady 6 Monkey. 
In both cases the additional element is situated on the rim of the garment, suggesting that actually the difrasismo (hendiadys) Dzico Huatu 'Power and Glory', of respectively the knives and the plumed serpent, is meant."

There are alternative representations of both dzico and huatu. As dzico is also the term for a red tunic (known with the Nahuatl term xicolli), which is worn by male rulers, this tunic appears as the "male representation" of the same word. Huatu can also mean 'braids'. We find both terms in these alternative representations in the given names of a brother and a sister: Lord 11 Flower 'Tunic of Clouds', i.e. Dzico Huico 'Power of Clouds', and Lady 5 Wind 'Braids of Clouds', i.e. Huatu Huico 'Glory of Clouds'. ${ }^{10}$

Nearly half of the Codex Yuta Tnoho (Vindobonensis), namely pp. 22-5, contains a series of rituals celebrated for the foundation of village-states and dynasties. ${ }^{11}$ These scenes start with sets of signs that seem to refer to elaborate discourses and ritual acts. The central topic of the ritual is explicitly indicated by a sign in the beginning, composed of a cradle (dzoco, also: 'sanctuary', and, as a verbal stem: 'to dedicate') and the frieze with the step-fret motif: nuu 'town'. The combination, both iconically and phonetically, refers to the foundation and dedication of towns.

In these lists of signs that represent the elaborate discourses for the foundation of settlements we encounter pairs of tunics (p. 22 and p. 18). The basic word painted here is obviously dzico 'tunic'. In addition a lower band or rim is emphasized in the painting: we now understand that sign as huatu. In the first tunic the rim contains a frieze with the multicoloured step motif, the sign for $\tilde{n} u u^{\prime}$ town'. The band or rim in the second tunic is marked as a frieze of disks, which is the pictorial convention for anine 'palace' (in Nahuatl: tecpan). ${ }^{12}$ Thus, the combination refers to the power and the glory of cities and palaces. The second tunic has cords of jade, adding the adjective "precious". Furthermore it is multicoloured and striped, a motif that usually refers to rock

9. See Codex Añute (Selden), p. 5-IV and p. 6-I (facsimile edition and commentary: Jansen \& Pérez Jiménez 2007b).

10. See Codex Ñuu Tnoo - Ndisi Nuu (Bodley), p. 30-III (photographic reproduction with commentary: Jansen \& Pérez Jiménez 2005).

11. See Anders \& Jansen \& Pérez Jiménez 1992a and Jansen \& Pérez Jiménez 2007a.

12. The town's palace is glossed 'aniñe' on the first page of the Codex of Yanhuitlan (Sepúlveda y Herrera 1994, lam II). Batalla Rosado (1997) has identified the tecpan glyph. 
(cavua, toto) and therefore may allude here to the expression yehe toto, which means "orderly". Simultaneously the pairing of a "normal" tunic with a "rocky" tunic is a symbolic reference to the two successive "peoples" or rather social orders of Nuu Dzaui: the "normal" Lords, proceeding from Yuta Tnoho (Apoala), and their mythic predecessors, the Stone Men, who turned into stone at the first sunrise of the new epoch. Other paired signs in this context are:

- "pulque (ndedzi) and chocolate (dzehua)",

- "altar (chiyo) and pyramid staircase (ndiyo)",

- "blood and heart" (neñe ini, a difrasismo for 'child', 'kinship' and 'sustenance'),

- "arrows, spear thrower, and shield" (nduvua cusi yusa, a general expression for 'fighting forces').

In these and several other cases the ordering of the signs is clearly in pairs and therefore may be interpreted as the representation of the parallelisms of ceremonial speech. ${ }^{13}$

In scenes in Codex Yuta Tnoho, see Fig.10, - as well as elsewhere in pre-colonial iconography - we find also the sign that may represent precisely the concept of ceremonial discourse: it consists of four volutes (which denote 'speaking'), in four different colours (referring to the four directions), bound together. We may reconstruct its meaning as 'speaking to the four directions' or 'ritual speech', being used as a general sign for 'ritual' or 'fiesta' (huico). On an early colonial carved stone from the Dominican convent of Cuilapan, the same sign appears to designate specific Mixtec "months" or rather twenty-day periods, named after specific rituals. The fact that this sign is based on that for 'word' suggests a connotation of the synonymous difrasismos huidzo dzaha and huidzo sahu 'word of the lord(s), law'. In colonial times these expressions came to denote 'preaching, doctrine', while on the other hand tay yocaha huico '(the) man who speaks the feast', came to designate an 'idolatra'. The sign of the four bound volutes occurs prominently in the sequence of foundation rituals that occupy a significant part of Codex Yuta Tnoho. We find it combined with wood and rubber balls, to be burned as offerings, and with an ear being pierced by a bone perforator, a sign of self-sacrifice (pp. 22, 17). It also

13. Codex Añute (Selden), p. 3, contains a similar constructed scene, which seems to be a ceremonial discourse in the context of an enthronement ritual (Jansen \& Pérez Jiménez 2007b). 
appears together with the signs for 'deity' ( $\tilde{N} u h u)$ and for a sacred bundle of sticks (pp. 18, 17).

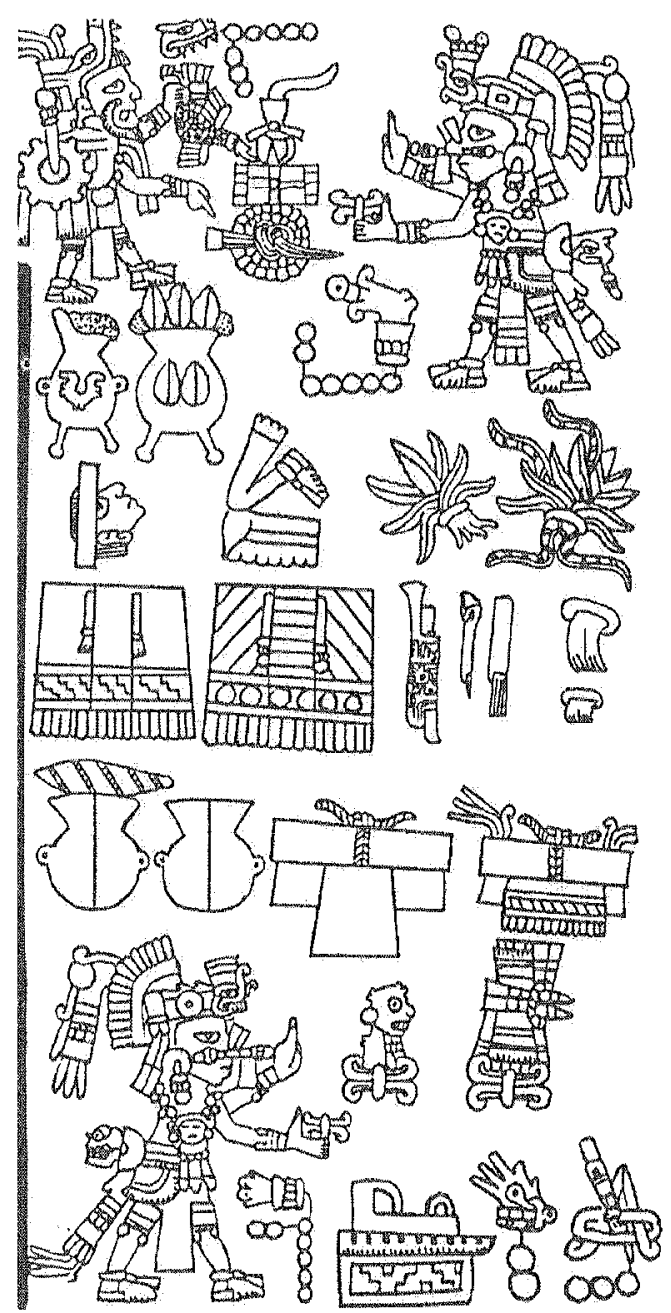

Fig.10. Codex Yuta Tnoho (Vindobonensis), p. 18: beginning of the foundation ritual (reading order: from bottom to top).

Another, more indirect but illustrative reference to the special ceremonial speech may be found in the same sequence of images. After the reference to a ball game we find the sign of a mouth spitting out dark 
powdered stuff with balls of down, followed by the combination of a split stick and a banner. The mouth with dark powder, we propose, may be read as yaa 'ashes', used to represent the homonym yaa 'music, song'. The feathers of the down ball are used, for example, to consecrate sacrificial victims. ${ }^{14}$ We therefore interpret them in Dzaha Dzaui as ii 'delicate, sacred' or huii 'soft, nice, honourable'. The combination yaa huii is mentioned by Alvarado as 'sweet and soft song' (Spanish: dulce $y$ suave canto). The split decorated stick may be read as the word dzee, verbal stem of 'to split' (Spanish: hender, tajar), but also, as an adjective, meaning 'happy' and 'peaceful'. The word for banner is huayu, which also means 'elegant, nice, graceful', especially in combinations with 'speaking' or 'singing': to speak elegantly is yocaha huii, yocaha huayu. Consequently we read this whole sequence (yaa huiidzee-huayu) as a reference to sweet, happy and elegant songs.

\section{Terminology for ancient activities and artefacts}

Part of the foundation rituals is dedicated to the preparation of pulque, the alcoholic beverage made from the juice of the agave or maguey plant (pp. 22, 20, 13). This passage in the text follows the phrase on nice speech discussed above and starts with a general opening statement referring to "the thirteen rosettes, the rosettes of bound grass", which are similar to the present-day wreaths of the cucharilla plant (tiyeye in Alvarado, chichi in Chalcatongo today), made to decorate altars, churches and arches at festive occasions.

As shown in Fig.11, there are two walking personages: an opossum (tlacuache) and a decapitated woman who is dressed as Lady 9 Reed in a huipil 'long dress' and a skirt decorated with flint knives. Both are carrying two bowls (jicaras) in their hands topped with flint knives. They proceed towards three maguey plants, the first of which has a human face and a hand, making the gesture of lamentation or woe, the second has green and black leaves and in the third a decapitated man is seated. 


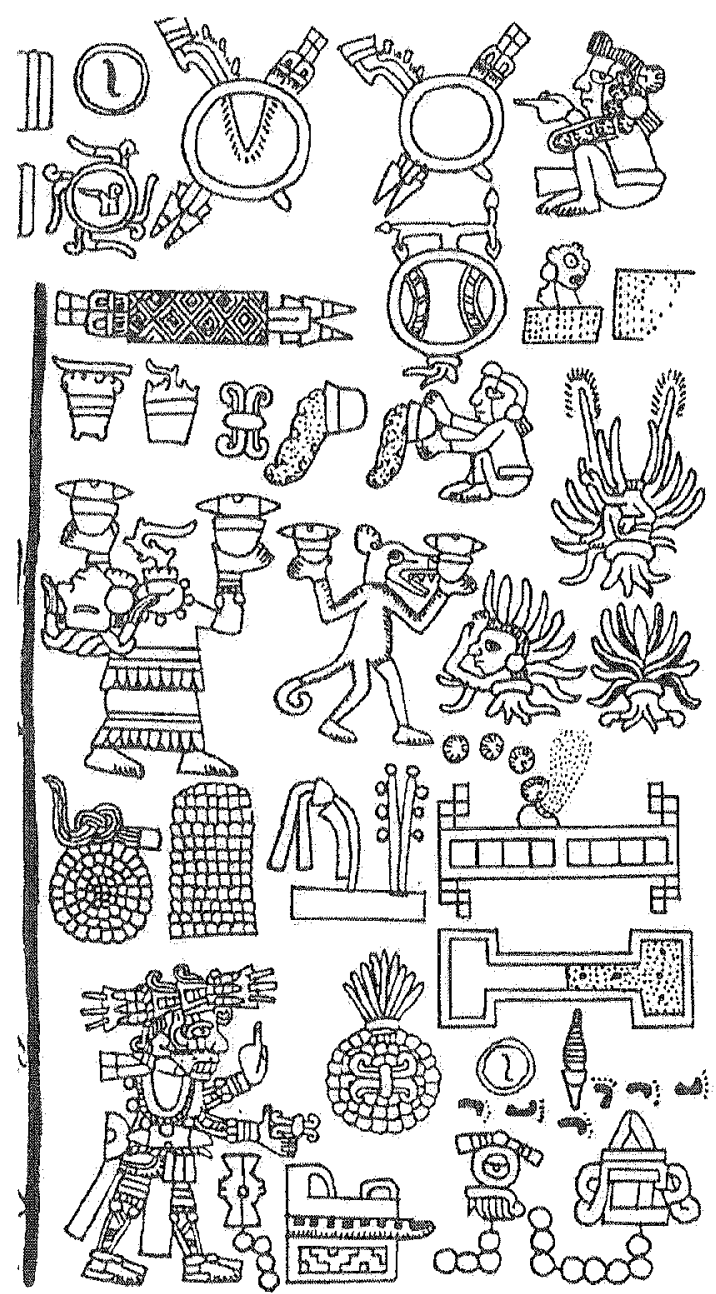

Fig.11. Codex Yuta Tnoho (Vindobonensis), p. 20: the cutting and scraping of the maguey plants in the context of a ceremonial discourse during the foundation ritual, (reading order: boustrophedon, from bottom to top).

The scene becomes understandable if we compare it with present day oral traditions. ${ }^{15}$

15. We thank Mrs. Rosa Pilar Jiménez Jiménez, Mr. Felipe Pérez Cruz and Mr. Isauro Nicolás Jiménez, all experienced maguey cultivators from Nuu Ndeya (Chalcatongo), for their orientation and explanation, provided in Sahin Sau. 
Onde anaha shraan, tu jiniyo na kuia, na kiu nindukoo Iha Nducha Kuijin, ndiyi tatañuuyo, ndiyi nanauyo nikajini ja nikatava, nikasha nducha kuijin ja yoo onde vina, yoo ndasi kuia ja yoo nducha kuijin.

Very far in the past, we don't know in which time (which year, which day), Lord Pulque was seated (established himself), our defunct grandfathers, our defunct grandmothers knew how to make and create the pulque that exists until today, since immemorial times there is pulque.

Tu ni in ñuu, teyu, ja katava nducha kuijin, ja kuu saha nducha kuijin. Kanuu ndau nducha kuijin ja kuu nducha kuijin jaa.

There is no other country (place, throne), where people know how to make pulque, how to make new pulque. The chinastle (mother pulque) is essential to make new pulque.

Katahu yau te kañii jiin yuchi yau, ja kuu yuchi maa yau.

People cut the maguey, and scrape it with the knife for the maguey, the special knife for the maguey.

Katahu yau nuu ninachitu yoo chi suan ndeya nducha kuijin te asuka jihi.

They cut the maguey when it is full moon because so the pulque is more abundant and has better taste.

Ja kitahu yau kajantiun machete, yuchi, barreta luli, shi yunu ja yo punta. shini ja kuu kuenta palanka.

For cutting the maguey they use a machete, a knife, a small barrette or pointed spade as lever.

Tini nuu yau yoo: sakuniyo yau isa, yau kuijin yau kuii, uan kakuu ja kajaha nducha kuijin.

There are several types of maguey: for example maguey of large leaves, white maguey, green maguey, these are the ones that give pulque.

Nducha kuijin yau kuii chi tu asu jihi, chi nakuha shiko maa yau uan.

The pulque from the green maguey does not taste well, because it conserves the taste of the maguey plant itself.

Nuu nijaha ja niyisha kanti yutu te jaa ita yau, kakaya. Kayee ita yau.

When the plant is old, the quiote (stem) comes out with flowers, the cacayas, which are eaten.

Nuu nindihi nijaha ndushi te ichi maa yau nduku nikanduu.

When the plant finishes producing juice and dries up, it becomes just wood. 
Toho yii tahu yau, suni maa toho yii sa-ii, nakuatu jiin yiti, jani in yajin nducha kuijin nuu mesa Chuhchi, te nakuatu jiin nducha kuijin te chuhun tihi ñi nuu yajin nducha kuijin, ja nakuatu jiin uan, te jiin maa ndishri ja kuu $i$, ndrishri ndau, ndishri nuu, te nasketahan ni, te nakuatu jiin ndihi ndishri uan.

A man cuts the maguey, he also blesses it with a candle, places a gourd with pulque on the altar of the Saints, prays with the pulque, throws a little bit of salt into the gourd with pulque, with which he is praying, and on the same pulque that is being blessed, the chinastle (pulque madre), the original pulque, he mixes them and prays with all the pulque.

Ja kihin kisa-ii ndushi yau jiin ndau nducha kuijin, nakuatu te chiñuhma jiin susiakutu, kayu yiti ñuma, kuyaa ñi, nducha ii, te koho in yajin nducha kuijin jiin maa Ñuhu Ndehyu.

In order to bless the juice and the chinastle (mother pulque) he prays and incenses with copal, with a burning candle, salt, holy water, and he drinks a gourd (jícara) pulque with God Earth.

Nu tunu nducha ii yoo te jiin maa ñi ni, te chiso cruz kuiko yuhu tindoho luli nducha kuijin uan.

If there is no holy water, then (he will do the blessing) just with salt, making the sign of the cross around the small jar of pulque.

Toho sthi kuu ja jañii yau, ndekiu jaha ndushi, tahan shian ñaha janakiinto ndushi, te tahan añini janakiinto ndushi, ja kiu nuu nducha kuijin uan, nuu ninakihinto ndushi, te uan ñito jiin yuchi maa yau, tava jaco yau, ñito sandooto ini yau yáu, suan ndukuhun maa ndushi.

The woman is the one who scrapes the maguey, all the days the maguey produces juice (aguamiel), each day in the early morning she goes to collect the maguey juice, and each late afternoon she goes to collect it, so that it is added to the pulque. When she collects the maguey juice, she scrapes the plant with the knife for the maguey, takes out the pulp of the maguey she scraped, cleans the hole in the maguey; so the juice accumulates there.

Tahan shian ñaha te tahan añini ndí ndushi nuu nducha kuijin, te ndeya nducha kuijin.

Each early morning and each late afternoon the maguey juice is added to the pulque so that the pulque becomes abundant. 
Jahan ndau shrahanka, tihi ndau te chuhun ndushi nuu ndau te ndeya nducha kuijin, te kejaha kuyahu, kuenta uhun peso, ushi peso shi kuenta tindoho, kuenta kiyi.

First goes the chinastle (mother pulque), a bit of it, and maguey juice is added to it, it becomes abundant and ferments; then it is sold for five, ten pesos or by jars, by vessels.

Tu kasndihi ndishri, kasndoho joo ja kuu ndau, te jiin ndau kanasaha ndishrijaa.

They don't finish all the pulque, they reserve some as chinastle (mother pulque), with which they can make new pulque.

Nuu nindihi niñiito yau uan te jasu nuu yau yáu uan ja ma kíu nducha sau jiin mihi nuu ndushi, te koo jako ndushi, ma kuuka kiu nuu nducha kuijin chi stiu ndishri uan.

When she finished with scraping the maguey, she covers the hole in the plant so that rain water does not enter in the juice, nor filth, which would spoil the pulque.

Kasu jiin sahma ndoo, te sikt sahma kasu jiin plastico, uan te kainto ndaha maa yáu siki sahma jiin plastico ja ma ndeche jinaha.

She covers it with a clean piece of cloth, and with plastic on top of that, and she puts some maguey leaves on top of the cloth and the plastic so that the wind does not carry them off.

Suni ja ma kihin jako kikoho ndushi, chi shraan tintini jako koho ndushi. Also in order that the opossum (tlacuache) does not drink the maguey juice because the oppossum really likes to drink the juice.

Remembering how the codex scenes represent the parallelisms of ceremonial speech, we interpret the two walking figures as a double reference to one individual, who proceeds towards the maguey plants with bowls and knives. The knife in this context is most probably the implement (still known as yuchi 'knife') used for cutting and scraping the maguey (Spanish: raspar el maguey) in order to extract the juice, aguamiel, for preparing the alcoholic beverage pulque (see also Mak 1977; Concuera de Mancera 1997).

Interestingly enough, the shape of the special knife used for scraping the maguey resembles the crescent form of the Andean tumi. A similarly shaped copper artefact appears in an archaeological context 
at the Mixtec coast and indicates the introduction of metallurgy through trade from the South during Postclassic times.

There are different types of maguey that can be used to this effect, likely represented by the three magueys in the codex. With alarm (sign of lamentation) they await what is going to happen to them: the cutting and scraping (yotahui) is represented as a decapitation.

The opossum, who is known in sacred stories as the animal that brought pulque to the world, walks in front. ${ }^{16}$ We may read this animal as a symbolic representation of the man who is going to cut the maguey. Behind him comes a woman: she is painted as being decapitated herself, but in this context we prefer to read this image as a pictorial combination of an individual and the act of decapitation, i.e. as the person (likely indeed a woman) who is going to decapitate the maguey. Logically she is dedicated to Lady 9 Reed, the Goddess who represents the power of the knives. Reading this in the context of the preparation of pulque, we understand that the subjects of the actions are paralleled as "the opossum man who is going to bring pulque to the world (by cutting the maguey) and the woman dedicated to Lady 9 Reed, who is going to decapitate, i.e. scrape the maguey".

The Divine Patron or Essence of the maguey is another Goddess, known as Mayahuel to the Nahuas and represented in the Teoamoxtli Group (Borgia Group) as seated on (ruling over) the maguey plant, an image that connects her with the contemporary veneration of the Virgen de los Remedios 'Virgin of the Remedies', who also manifested herself on a maguey and is the Patron of the process of preparing pulque. This identification (part of a much wider and complex religious interaction and mutual translation process, referred to as "syncretism") goes back to early colonial times.

Nuu ndaha yau ndukoo Iha Siht Yau.

On the leaf of the maguey is seated the Lady of the Maguey [the Virgen de Los Remedios].

Viko Iha Sith de los Remedios kuu maa kiu una yoo diciembre te suni kiu uan kuu viko Iha Siht Juquila, viko Tha Sthi de los Remedios kasaha nuu Yucha Naichi, Nuu Ndeya, te viko tha Siht Juquila kuu maa Nuu Santa Maria Juquila.

16. See Van der Loo 1987: 157 ff. and 179 ff. A parallel scene is found in Codex Tonindeye (Nuttall), p. 3 (facsimile edition with commentary: Anders \& Jansen \& Pérez Jiménez 1992b). 
The feast of the Virgen de los Remedios is the 8th of December, which is also the day of the feast of the Virgin of Juquila; the feast of the Virgen de los Remedios is celebrated in the community of Chapultepec, Chalcatongo, and the feast of the Virgen de Juquila is in the village itself of Santa Maria Juquila.

Lady 9 Reed in Codex Yuta Tnoho (Vindobonensis), p. 28 has the diagnostic face paint of Mayahuel (the lower half of her face is coloured blue). ${ }^{17}$ While her face paint connects her to the maguey plant; the knives in her name or title identify her specifically as the Patron (or power) of the knife that cuts the maguey.

Still today the diverse acts of pulque production are imbued with religious meaning:

Ja tahu yau kahanyo, kakanyo nuu maa Ñhu Ndehyu nakuaha ja kuu kitahuyo yau chi maa Nuhu Ndehyu kuu jitoho ndiht ja yoo nuu ñuyiu yaha.

For cutting the maguey we speak and ask to God Earth, so that he may give us permission to cut the maguey, because God Earth is the lord of all that exists in this world

Iha Sthi de los Remedios kuu jitoho maa yau suni.

Also to the Virgen de los Remedios, who is the Patron of the maguey.

Nakuatuyo:

'Kuahani, Nuhu Nehyu,

sehe ndahu sehe keeni,

nichaana nuu iyaani,

nuu iyaa seheni man yau,

veina vestujina seheni ja kuu maa yau.

Ma kiti-inini nuuna te kuahani permisu,

ja tahuna seheni yau yaha

nakuaha joo ndushi ja kuu Iha Ndishri.

Iha Sihi de los Remedios,

San Cristobal, San Cristina, Santo Lugar.'

17. See for example Codex Mictlan (Laud), p. 16, and Codex Yoalli Ehecatl (Borgia), p. 68 (facsimile editions with commentaries: Anders \& Jansen 1994; Anders \& Jansen \& Reyes García 1993). The iconography reproduces the link of Mayahuel with the Goddess of Water, Chalchiuhtlicue (see also Loo op. cit.). 


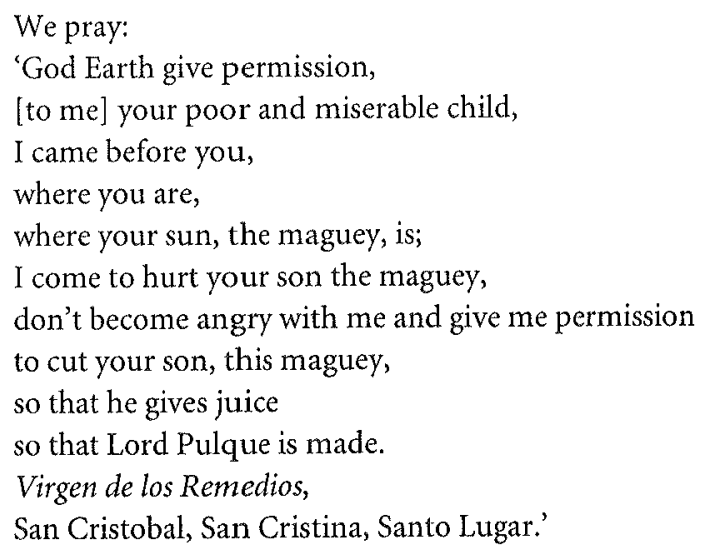

The Earth God, Nuhu Ndehyu, is the present-day manifestation of the $\tilde{N} u h u$, a general concept of divine power, mentioned in Alvarado's vocabulary as "Dios", and represented in the Mixtec codices as a red stony figure. Today this being is invoked as the trinity of "San Cristobal, San Cristina, Santo Lugar", present throughout the landscape and the epitome of Nature as a superhuman force. The maguey plants are explicitly defined as children of the Earth God.

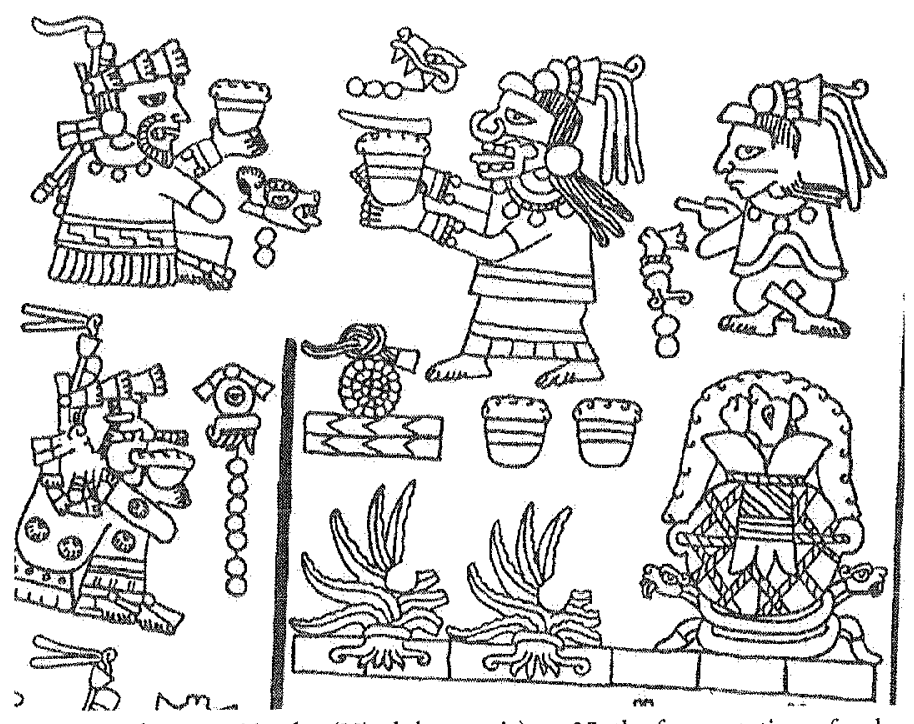

Fig.12. Codex Yuta Tnoho (Vindobonensis), p. 25: the fermentation of pulque. 
In Codex Yuta Tnoho (Vindobonensis), p. 25, we see a scene of drinking of newly made pulque. The opening scene consists of strips of land with maguey plants and a pulque jar. Then two ladies, both dedicated to the Maguey Goddess, serve pulque to a whole group of primordial personages. The maguey plants are cut - we observe how they are hollowed out in order to extract their juice. A correct detail is that the lower maguey leaves (ndaha yavui, in Spanish called penca de maguey) are cut off to facilitate approach by the cutter / scraper. The pulque jar is guarded by divine and dangerous powers (represented by coiling snakes). Pulque is rising (fermenting), and in it is the face of the maguey goddess. The face itself also is to be read as the verb yonana 'to sprout, rise'. The religious element is present until today: maguey juice is poured on a remainder of earlier made pulque, known as ndau in Chalcatongo, which is translated with the loan word from Nahuatl chinastle or in Spanish as pulque madre. The mixture is left to ferment under or next to the house altar.

These actions parallel the ritual character of the scene in the codex, which finishes with a priest spilling white liquid from a bowl, after which a reddish-brown liquid with dots is spilled as well. The sign for ritual (speaking to the four directions) is given, followed by a bowl of blood and a bowl of white liquid topped with a maguey leaf. Given the presence of maguey plants, the white liquid has to be pulque (nducha kuijin 'white water' in Chalcatongo today). The reddish, dotted variant may be the maguey juice or a derived drink such as tepache. The bowl of blood reminds us of the above-mentioned Mixtec and Mesoamerican metaphor in which blood is part of sustenance (neñe ini).

Nducha kuijin kuu in nducha kanuu, chi kajihi ñaiu nuu kasatiun, sa kuniyo nuu kachihi itu, shi natiun ndaku.

Pulque is an important drink, because people drink it when they are working, for example when they are planting the fields or doing similar work.

Nu kinakana suni kanuu nducha kuijin ja kihin koho maa Ñuhu Ndehyu kihin in tindoho.

When they are going to do a cleansing ritual, pulque is also important, it goes for God Earth to drink, there goes a jar. 
Nuu yahu kuu ja kashiko kuaha nducha kuijin kin yahu yaha

In the market place it is the case that a lot of pulque is sold, on market days.

Ja kani nducha kuaha kajantiun in tindoho kahnu nducha kuijin jiin panela, shraanka nduha panela ini kisi nducha nijiso te suan nducha panela uan

In order to prepare tepache they use a big jar of pulque with panela; first they boil the panela in a large cooking vessel with water and so the panela is dissolved.

Toho siht ja jani nducha kuaha kichiñuhma nuu kundii kisi nducha kuaha, chiñuhma jiin susiakutu te kati ndishri nuu Nuhu Ndehyu,

sakuaha nakee vaha nducha kuaha, te suni ja ma tahu maa kisi uan.

The lady who prepares the tepache will incense the place where the vessel with tepache is placed, she incenses with copal and sprinkles aguardiente before the Earth God so that the tepache may result well and so that the vessel of the tepache will not break.

Nuu nijiso nducha panela te chuhun ini kisi nuu kuu nducha kuaha, uana te chuhun in tindoho kahnu nducha kuijin nuu nducha panela, wana te kundihu yuhu jiin in sahma jaa, kundii uni kiu te nduu nducha kuaha.

When the water with panela has boiled, it is poured into the vessel in which the tepache is going to be made. Then a big jar of pulque is poured on to the water with panela, the vessel is closed off with a new piece of cloth: it will stand there for three days and so (by fermenting) it becomes tepache.

Pulque is of great cultural historical significance and remained so in colonial times, be it under different circumstances (Concuera 1997). It became part of the tremendous wave of alcoholism that pervaded the region together with colonialism and kept it in its grip until very recently, machismo and domestic violence being directly related phenomena. Nowadays new beverages are introduced as hallmarks of neocolonial consumption patterns.

Vina tuka kajihi shraan nducha kuijin. Joonika kajihi, tuka kajantiun nducha kuïin, chi vina kajihika refrescu jiin cerveza.

Nowadays people do not drink much pulque any more. They only drink a little, and do not occupy themselves with pulque any more, because nowadays they drink more soft drinks and beer. 


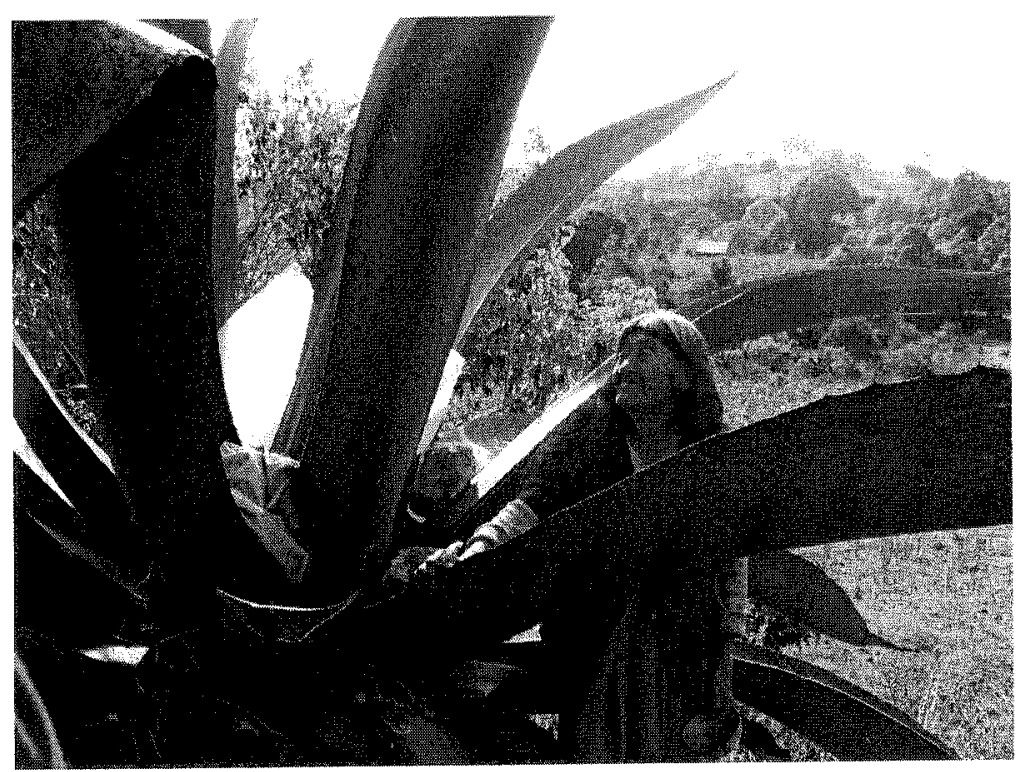

Fig.13. Scraping the maguey, Chalcatongo.

\section{Concluding remarks}

The examples discussed above show how Nuu Dzaui (Mixtec) pictorial manuscripts contain many specific terms of the Nuu Dzaui cultural vocabulary, as well as the typical parallel structures and metaphors of the ceremonial speech, reported as the "lordly language" by Friar Antonio de los Reyes. This lends support to the hypothesis that the codices were read, i.e. taken as the basis (script, story-line) for a declamatory performance in a ritual setting. The use of a special ceremonial "lordly" language conveys the notion that the terms were codified by others in a (sacred) past. Just like the other ritual acts, these wordings include a moral reference, to which the participants commit themselves openly by their very act of participating. ${ }^{18}$ The rituals and the corresponding ceremonial speech are therefore appropriate to mark the crucial moments that articulate and construct social life.

The structure of this language, in combination with specific terms from the cultural vocabulary, present in colonial works as well as in oral traditions, helps us to read and understand ancient pictography.

18. See the insightful studies by Rappaport (1999), and Keane (in Duranti 2004). 
On the other hand, reconnecting codices and other historical texts of profound contents to on-going traditions and oral literature not only evidences long-term cultural continuity, but also fosters memory and identity.

This cultural continuity is an obligatory reference for the study of native works in a specific cultural tradition, be it in the past or the present. As such, it permits us to transcend the extremely limited and fragmentary character of archaeological remains, as well as the bias and time-bounded nature of historical documents by connecting the data from these sources to culture as an alive, dynamic, rich and often unpredictable process, with its many details, its own "logic" and its internal human drama and contradictions. But cultural continuity should not just be taken as a reservoir of illustrative data for putting flesh on the skeletons of the past, nor for suggesting interpretations of otherwise enigmatic aspects of archaeological artefacts or monuments. Cultural continuity, in the first place, imposes a need on scholars to take into account the very presence and co-evalness of existing peoples as subjects (cf. Fabian 1983).

In Mexico, as elsewhere in the Americas, the crucial point of reference in studies of the native languages and cultural histories is the European colonial invasion. This incisive and traumatic experience created a marked difference between (a) the descendants of the colonizing groups, (b) the indigenous peoples, who still remain in a subjugated, exploited situation, and (c) other subaltern segments of society. The historical conquista is not a closed chapter of the past, but an "open vein" in present-day processes of globalisation, or rather neocolonialism, and the pervasive internal colonialism instigated and maintained by the dominant westernised / westernising strata inside the country itself, often in combination with nationalist ideologies. As a consequence, indigenous peoples continue to be victims of marginalisation, discrimination, social injustice, and territorial-cultural loss. At the same time the colonial structures, points of view, and conceptualisations still haunt collective memory on both sides of the ocean and influence present-day discourse, thought and scholarly practice.

From the Spanish chroniclers and missionaries in the $16^{\text {th }}$ century up to modern archaeology, (ethno)history, anthropology and linguistics, the interpretive paradigms have always been "Western". This has obscured understanding in several aspects. Until very recently, for example, it did not occur to investigators that the death imagery in 
Mesoamerican cultures might be related to ancestor cult (hardly present in Western worldview) instead of some macabre "fascination with death and - of course - human sacrifice". In a more general sense, Western investigators tend to see Mesoamerican religion in terms of theory and dogma, more than as living experience, and so tend to stress dichotomies, which may not always be relevant. It is very "Western" to differentiate, for example, between the physical and the metaphysical realms, which were closely connected as complementary if not identical in Mesoamerican thought. The God of Rain or rather "Lord Rain", is rain itself, thus a qualification as "supernatural" is alien to the cultural context. A translation as "superhuman" may be a better reflection of Mesoamerican mentality.

After five centuries of colonialism, indigenous society shows resilience, innovation and growth. The past decades have shown an impressive rise in the consciousness and political activity of the peoples themselves, as well as in international attention, resulting, for example, in the adoption of a Declaration of Rights of Indigenous Peoples by the General Assembly of the United Nations Organisation (New York, 2007). ${ }^{19}$

Passing part of our lives in the Nuu Dzaui region, we, the present authors, are impressed by the agency of the native communities themselves. Being forgotten or hardly given attention in government policies, the inhabitants have realised an economic boom through their own hard work, be it locally in community projects with an unceasing search for funds and support, or, in a wider context, by conquering job opportunities abroad, e.g. through the hardships of national and trans-national migration. Several decades ago the general atmosphere of the region was very depressing, nowadays we see major construction activity in many places, while newly founded schools offer advanced education programs and a better communication is facilitated through paved roads and the introduction of computers, internet etc.

19. Obviously there are many studies and different reflections on this topic, loosely referred to as the body of Postcolonial Theory. We limit ourselves to mentioning some classic monographs that have specially inspired us: Memmi (1991), Wolf (1982), Lemaire (1986), and Bhabha (1994), as well as to the statements of the symposium ' $L a$ Visión India: tierra, cultura, lengua, derechos humanos' during the 46th International Congress of Americanists in Amsterdam, 1988 (Musiro 1989). See further our own articles on the subject (Pérez Jiménez \& Jansen 1979, 2006). 
However, given the recent past of ethnocide policies (castellanización) promoted and implemented by different governments, cultural awareness and emancipation are often still lagging far behind. Not being taught at school, nor being learned at home by the younger generation, the native languages are rapidly eroding and disappearing. Actually, most Mesoamerican languages are already extinct, but - misleadingly - keep appearing in the census, as their last speakers are still alive. There are a few well-meaning reinforcement projects but these remain often stuck in the experimental stage, suffering still from lack of means and real commitment (cf. Meyer \& Maldonado Alvarado 2004).

In this context the documentation, study and positive appraisal of the languages and cultures in this region has strong social relevance and potential for education and emancipation purposes, providing a cultural dimension for sustainable development. Research is timely but, in order to avoid perpetuating intellectual colonialism, should progress in a participatory manner, including explicitly and respectfully the knowledge, views and interests of the communities themselves. At the same time, research should avoid the essentialist and traditionalist trap of idealizing the indigenous culture and so freezing or disorienting its internal development. In sum, research should contribute to decolonizing and humanizing memory on both sides of the ocean.

\section{References}

Alexander, Ruth Mary (1980) Gramática Mixteca, mixteco de Atatlahuca. Mexico: Instituto Lingüístico de Verano.

Alvarado, Fray Francisco de (1962) (1593) Vocabulario en Lengua Mixteca. Mexico: Instituto Nacional de Antropología e Historia \& Instituto Nacional Indigenista.

Anders, Ferdinand \& Maarten Jansen (1994) Pintura de la Muerte y de los Destinos. Libro explicativo del llamado Códice Laud. Mexico: Fondo de Cultura Económica.

- (1996) Religión, Costumbres e Historia de los Antiguos Mexicanos. Libro explicativo del llamado Códice Vaticano A (Códice Vaticano 3738). Mexico: Fondo de Cultura Económica.

Anders, Ferdinand, Maarten Jansen \& G. Aurora Pérez Jiménez (1992a) Origen e Historia de los Reyes Mixtecos. Libro explicativo del llamado Códice Vindobonensis. Mexico: Fondo de Cultura Económica.

- (1992b) Crónica Mixteca: El rey 8 Venado, Garra de Jaguar, y la dinastía de Teozacualco-Zaachila. Libro explicativo del llamado Códice Zouche-Nuttall. Mexico: Fondo de Cultura Económica. 
Anders, Ferdinand, Maarten Jansen \& Luis Reyes García (1993) Los Templos del Cielo y de la Oscuridad: Oráculos y Liturgia. Libro explicativo del llamado Códice Borgia. Mexico: Fondo de Cultura Económica.

Assmann, Jan (1992) Das kulturelle Gedächtnis. Schrift, Erinnerung und politische Identität in fruhen Hochkulturen. Munich: Verlag C.H. Beckk.

Batalla Rosado, Juan José (1997) 'El Palacio Real Mexica. Análisis iconográfico escriturario'. In: Maarten Jansen \& Luis Reyes García (eds.), Códices, Caciques y Comunidades. Cuadernos de Historia Latinoamericana 5. Ridderkerk: Asociación de Historiadores Latinoamericanistas Europeos, pp. 65-101.

Bhabha, Homi K. (1994) The Location of Culture. London: Routledge.

Bradley, C. Henry \& Barbara E. Hollenbach (eds.) (1988/92) Studies in the Syntax of Mixtecan Languages vols 1- 4 Summer Institute of Linguistics, publications 83, 90, 105, 111, Arlington: University of Texas.

Braidotti, Rosi (1994) Nomadic Subjects. Embodiment and sexual difference in contemporary feminist theory. New Cork: Columbia University Press.

Concuera de Mancera, Sonia (1997) El fraile, el indio y el pulque. Evangelización y embriaguez en la Nueva España. Mexico: Fondo de Cultura Económica.

Córdova, fray Juan de (1578) Vocabulario en Lengua Capoteca. Pedro Charte y Antonio Ricardo, Mexico. Facsímile edition (1987). Mexico: Ediciones Toledo.

Duranti, Alessandro (ed.) (2004) A Companion to Linguistic Anthropology. Oxford: Blackwell.

Dyk, Anne (1959) Mixteco Texts. Norman: Summer Institute of Linguistics.

Dyk, Ann \& Betty Stoudt (1973) Vocabulario mixteco de San Miguel el Grande. Mexico: Instituto Lingüístico de Verano.

Fabian, Johannes (1983) Time and the Other. How anthropology makes its object. New York: Columbia University Press.

Faraclas, Nicholas (1983) 'Preliminaries to Tonemic and Tonomechanical Analysis for the Chalcatongo Dialect of Mixtec'. Studies in Mesoamerican Linguistics, report $4: 307-331$.

Flannery, Kent \& Joyce Marcus (eds.) (1983) The Cloud People:Divergent Evolution of the Zapotec and Mixtec Civilizations. New York: Academic Press.

Geurds, Alex (2007) Grounding the Past: the praxis of participatory archaeology in the Mixteca Alta, Oaxaca, Mexico. Leiden: CNWS Publications.

Hernández, fray Benito (1568) Doctrina Christiana en Lengua Mixteca. Mexico: Casa de Pedro Ocharte.

Hernández Sánchez, Gilda (2005) Vasijas para Ceremonia. Iconografía de la Cerámica Tipo Códice del Estilo Mixteca Puebla. Leiden: CNWS Publications.

Hinton, Leanne (1991) An Accentual Analysis of Tone in Chalcatongo Mixtec. Occassional Papers on Linguistics 16 (James E. Redden ed.): 173-182. Carbondale: Southern Illinois University.

Jansen, Maarten (1994) La Gran Familia de los Reyes Mixtecos. Libro explicativo de los llamados Códices Egerton y Becker II. Mexico: Fondo de Cultura Económica.

- \& G. Aurora Pérez Jiménez (2004) Renaming the Mexican Codices. Ancient Mesoamerica 15: 267-271. Cambridge: University Press.

- \& (2005) Codex Bodley. A Painted Chronicle from the Mixtec Highlands, Mexico. Oxford: Bodleian Library.

- \& - (2007a) Encounter with the Plumed Serpent. Drama and Power in the Heart of Mesoamerica. Boulder: University of Colorado Press.

\& (2007b) Historia, literatura e ideología de Ñu Dzaui. El Códice Añute y su contexto histórico-cultural. Oaxaca: Instituto Estatal de Educación Pública. 
- \& Luis Reyes García (eds.) (1997) Códices, Caciques y Comunidades. Cuadernos de Historia Latinoamericana 5, Ridderkerk: AHILA (Asociación de Historiadores Latinoamericanistas Europeos).

- \& Laura N.K. van Broekhoven (eds.) (2008) Mixtec Writing and Society / Escritura de Nuu Dzaui. Amsterdam: Royal Netherlands Academy of Arts and Sciences.

Josserand, J.Kathryn (1983) Mixtec Dialect History. PhD thesis, Tulane University, New Orleans.

Josserand, I. Kathryn, Maarten Jansen \& Ma. de los Angeles Romero (1984) Mixtec Dialectology, inferences from linguistics and ethnohistory. Essays in Otomanguean Culture History (J. Kathryn Josserand et.al. eds.): 141-225. Nashville: Vanderbilt University Publications in Anthropology 31.

Lemaire, Ton (1986) De Indiaan in ons bewustzijn. De ontmoeting van de Oude met de Nieuwe Wereld. Baarn: Ambo.

López García, Ubaldo (2007) Sa'vi. Discursos ceremoniales de Yutsa To'on (Apoala). $\mathrm{PhD}$ thesis Leiden University.

Loo, Peter L. van der (1987) Códices, Costumbres y Continuidad. PhD thesis, Leiden University,

Macaulay, Monica (1996) A Grammar of Chalcatongo Mixtec. University of California Publications in Linguistics Vol. 127, Berkeley: University of California Press.

Mak, Cornelia (1977) 'Maguey Tapping in Highland Mixteco'. Tlalocan VII: 115-119.

Memmi, Albert. (1991) The Colonizer and the Colonized. Boston: Beacon Press.

Meyer, Lois \& Benjamín Maldonado (eds.) (2004) Entre la Normatividad y la Comunalidad. Experiencias educativas innovadoras del Oaxaca indigena actual.. Oaxaca: Instituto Estatal de Educación Pública.

Molina, fray Alonso de (1571) Vocabulario en lengua castellana y mexicana. Casa de Antonio de Spíndola, México. New edition with introduction by Miguel LeónPortilla (1977). Mexico: Porrúa.

Musiro, Stichting voor Indiaanse Cultuur (ed.) (1989) La Visión India: tierra, cultura, lengua y derechos humanos. Leiden: Archeologisch centrum.

Nowotny, Karl Anton (1959) 'Die Hieroglyphen des Codex Mendoza: der Bau einer mittelamerikanischen Wortschrift' Mitteilungen Museum für Völkerkunde und Vorgeschichte Hamburg, XXV: 97-113.

Pérez Jiménez, G. Aurora \& Maarten Jansen (1979) 'Los códices y la conciencia de ser indigena'. Revista Mexicana de Ciencias Politicas y Sociales 97: 83-104. Mexico.

_. \& $\quad(2006)$ 'Native Culture and Colonial Structure'. In Laura van Broekhoven (ed.) The Social and Linguistic Heritage of Native Peoples in the Americas. The struggle to maintain cultural particularity pp. 177-219. Lewiston/Queenston: Edwin Mellen Press, / Lampeter.

Rappaport, Roy A. (1999) Ritual and Religion in the Making of Humanity. Cambridge: University Press.

Reyes, fray Antonio de los (1593) Arte en Lengua Mixteca. Mexico: Casa de Pedro Bailli.

- (1976) (1593) Arte en Lengua Mixteca. Nashville: Vanderbilt University Publications in Anthropology 14.

Ruiz de Alarcón, Hernando et al. (1953) (1629) Tratado de las idolatrias, supersticiones, dioses, ritos, hechicerías y otras costumbres gentílicas de las razas aborigenes de México. Mexico: Ediciones Fuente Cultural.

Schultze Jena, Leonard (1933-38) Indiana (3 vols). Jena: Gustav Fischer. 
Sepúlveda y Herrera, María Teresa (1994) Códice de Yanhuitlán. Mexico: Instituto Nacional de Antropología e Historia \& Benemérita Universidad Autónoma de Puebla.

Spores, Ronald (2007) Nu Nu Nudzahui, la Mixteca de Oaxaca. La evolución de la cultura mixteca desde los primeros pueblos preclásicos hasta la independencia. Oaxaca: Instituto Estatal de Educación Pública de Oaxaca.

Terraciano, Kevin (2001) The Mixtecs of Colonial Oaxaca. Nudzavui History Sixteenth through Eightteenth Centuries. Stanford: University Press.

Ve'e Tu'un Savi, Academia de la Lengua Mixteca (2007) Bases para la escritura de tu'un savi. Oaxaca: Secretaría de Cultura del Gobierno del Estado de Oaxaca.

Wolf, Eric R. (1982) Europe and the Peoples without History. Berkeley / Los Angeles / London: University of California Press. 